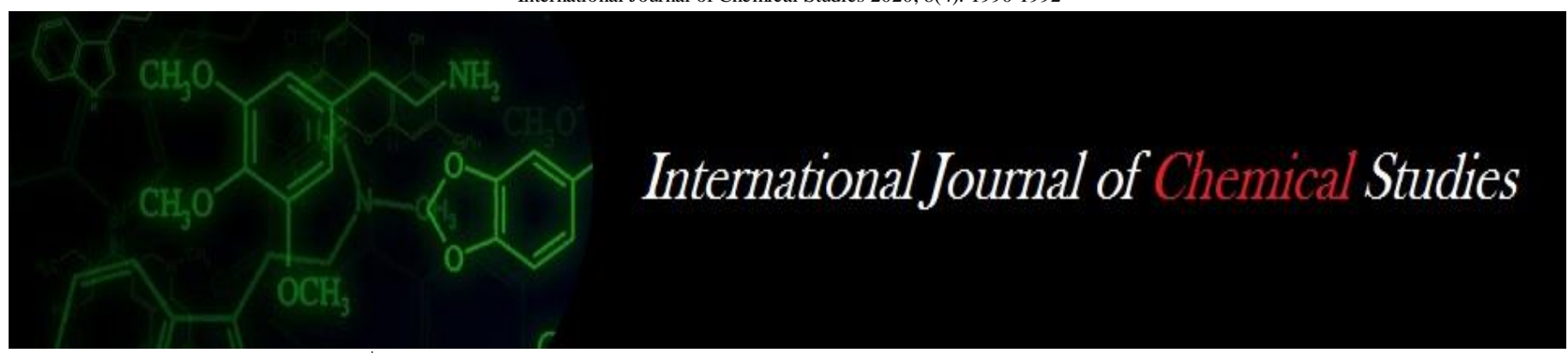

P-ISSN: 2349-8528

E-ISSN: 2321-4902

www.chemijournal.com

IJCS 2020; 8(4): 1990-1992

(C) 2020 IJCS

Received: 19-05-2020

Accepted: 21-06-2020

Ipsita Sahoo

M.Sc. Scholar, Department of

Agronomy, College of

Agriculture, Professor

Jayashankar Telangana State

Agricultural University,

Rajendranagar, Hyderabad,

Telangana State, India

Dr. Pindi Satish, Assistant Professor, Department of Agronomy, College farm, College of Agriculture, Professor

Jayashankar Telangana State

Agricultural University,

Rajendranagar, Hyderabad,

Telangana State, India

Syed Ahmed Hussain

Professor, Department of

Agronomy, College farm, College

of Agriculture, Professor

Jayashankar Telangana State

Agricultural University,

Rajendranagar, Hyderabad,

Telangana State, India

S Harish Kumar Sharma

Professor, Department of Soil

Science and

Agricultural Chemistry, College of Agriculture, Professor

Jayashankar Telangana State

Agricultural, Rajendranagar,

Hyderabad, Telangana State,

India

Corresponding Author:

Ipsita Sahoo

M.Sc. Scholar, Department of

Agronomy, College of

Agriculture, Professor

Jayashankar Telangana State

Agricultural University,

Rajendranagar, Hyderabad,

Telangana State, India

\section{Influence of integrated nutrient management practices on yield and economics of foxtail millet varieties}

\author{
Ipsita Sahoo, Pindi Satish, Syed Ahmed Hussain and S Harish Kumar \\ Sharma
}

DOI: https://doi.org/10.22271/chemi.2020.v8.i4u.9921

\begin{abstract}
A field experiment was conducted during kharif, 2019 at College farm, College of Agriculture, Professor Jayashankar Telangana State Agricultural University, Rajendranagar, Hyderabad. The soil of the experimental plot was sandy loam in texture, neutral in soil reaction, low in available nitrogen and organic carbon, low in available phosphorus and high in available potassium. The experiment was laid out in Factorial Randomized Block Design with 14 treatments and each treatment replicated thrice. Among the two varieties tested viz., SiA 3085 and SiA 3156, there were no significant difference in yield and economics of foxtail millet, both the varieties performed equally and found to be equally effective and remunerative in response to different organic and inorganic sources of nutrients. Among integrated nutrient management practices, 25\% RDN through Vermicompost $+75 \%$ RDF and 50\% RDN through Vermicompost $+50 \%$ RDF recorded significantly higher grain and straw yield over other combinations of organic and inorganic treatments. From economics point of view 25\% RDN through Vermicompost + $75 \%$ RDF found to be more remunerative.
\end{abstract}

Keywords: Foxtail millet, integrated nutrient management, yield, economics

\section{Introduction}

Foxtail millet (Setaria italica L.) is known as Italian millet, German millet and korralu, Kangu, Kangani, Koni and Kaon in different parts of India. It is one of the oldest crops cultivated for food, grain, hay and pasture. It ranks second in the total world production of millets and it continues to have an important place in world agriculture providing food for millions of people in arid and semiarid regions.

India is the largest producer of foxtail millet. In India it is largely grown in Andhra Pradesh, Telangana, Karnataka, Tamil Nadu, Uttar Pradesh and Southern Rajasthan. Andhra Pradesh, Karnataka and Tamil Nadu are the major foxtail millet growing states in India contributing about 79 per cent of the total area (Munirathnam et al., 2006) ${ }^{[5]}$.

It is generally grown as a rainfed crop in India. It has an erect leafy stem that grow $60-75 \mathrm{~cm}$ tall and bend quite a bit at maturity due to heavy weight of ear head. In $100 \mathrm{~g}$ of foxtail millet grain contains excellent source of good fibre $8 \mathrm{~g}$, protein $12.3 \mathrm{~g}$, carbohydrates $60.9 \mathrm{~g}$, fat 4.3 $\mathrm{g}$, calcium $31 \mathrm{mg}$, Iron $2.8 \mathrm{mg}$, phosphorus $290 \mathrm{mg}$, vitamins $3.3 \mathrm{~g}$, amino acids, minerals 3.3 $\mathrm{g}$ and food energy $323-350 \mathrm{~K} \mathrm{Cal}$ (Vanithasri et al., 2012) ${ }^{[8]}$. It has low glycemic index, so it is used for preparation of low glycemic index biscuits and burfi, a sweet product and it is an ideal food for people suffering from diabetes.

The soils in arid and semiarid regions are mainly deficient in nitrogen and inherently low in organic carbon because of rapid turnover rates of organic material due to higher soil temperature. With harsh climatic conditions and low soil fertility, effective nutrient management is of considerable importance to overcome the situations of limited yields in these areas. Thus low productivity in farmers' field in foxtail millet can be increased by adopting improved production technologies like integrated nutrient management.

Now a days, use of chemical fertilizer is increasing to boost up crop production. Simultaneously, cost of chemical fertilizer is increased constantly, besides these, only use of inorganic fertilizer is injurious to soil health and soil productivity. 
Integration of inorganic and organic fertilizers play a vital role for enhancing crop productivity and sustaining soil fertility, this proves great promise for farmers. Organic manure like vermicompost is a rich mixture of macro and micro plant nutrients. It also increases availability of nitrogen and phosphorus and improves microbial action in soil (Choudhary et al., 2014) ${ }^{[3]}$.

Hence integrated nutrient supply system involving sheep manure, organic manures like vermicompost, FYM in conjunction with chemical fertilizer is necessary to meet the nutrient demand besides improving physicochemical properties of soil. Since information pertaining to above aspects is meager, the present investigation was carried out to study the effect of integrated nutrient management on growth, productivity and nutrient uptake of foxtail millet.

\section{Materials and Methods}

The field experiment was conducted in College farm, College of Agriculture, Rajendranagar, Professor Jayashankar Telangana State Agricultural University, which is geographically situated at $17^{\circ} 19^{\prime} \mathrm{N}$ latitude and $78^{\circ} 23^{\prime} \mathrm{E}$ longitude at an altitude of $542.6 \mathrm{~m}$ above mean sea level. The soil of the experimental site was sandy loam in texture, neutral in soil reaction (7.56) and E.C. was 0.26. It was low in available nitrogen $\left(166.8 \mathrm{~kg} \mathrm{ha}^{-1}\right)$, available phosphorus $(22.1$ $\left.\mathrm{kg} \mathrm{ha}^{-1}\right)$ and organic carbon $(0.87 \%)$ and high in available potassium $\left(376.5 \mathrm{~kg} \mathrm{ha}^{-1}\right)$. The treatment consisted of two varieties viz., $\mathrm{SiA} 3085\left(\mathrm{C}_{1}\right)$ and $\mathrm{SiA} 3156\left(\mathrm{C}_{2}\right)$ as first factor and seven integrated nutrient management practices viz., Control ( $100 \%$ RDF -40-20-20 kg NPK ha-1) $\left(\mathrm{T}_{1}\right), 25 \% \mathrm{RDN}$ through Vermicompost $+75 \%$ RDF $\left(\mathrm{T}_{2}\right), 25 \%$ RDN through Farm Yard Manure $+75 \%$ RDF $\left(\mathrm{T}_{3}\right), 25 \%$ RDN through Sheep Manure $+75 \%$ RDF $\left(\mathrm{T}_{4}\right), 50 \%$ RDN through Vermicompost $+50 \%$ RDF $\left(\mathrm{T}_{5}\right), 50 \%$ RDN through FYM + $50 \%$ RDF $\left(\mathrm{T}_{6}\right), 50 \%$ RDN through Sheep Manure $+50 \%$ $\operatorname{RDF}\left(\mathrm{T}_{7}\right)$ as second factor comprising fourteen treatment combinations, laid out in randomized block design with factorial concept, replicated thrice.

Foxtail millet was sown during 16 July 2019 and harvested during 15 October 2019. Foxtail millet was planted at a spacing of $30 \mathrm{~cm} \times 10 \mathrm{~cm}$ using seed rate of $5 \mathrm{~kg} \mathrm{ha}^{-1}$. The required quantities of ( $25 \% \mathrm{~N}$ and $50 \% \mathrm{~N}$ through) farm yard manure, vermicompost and sheep manure were applied in respective plots as per the treatments and incorporated into soil two weeks before sowing of the crop. Nitrogen as per $\mathrm{N}$ levels $(100 \%, 75 \%$ and 50\% RD N) was applied through urea in three equal splits viz., 1/3 as basal, 1/3 at tillering stage (30 DAS) and the remaining $1 / 3$ at spike initiation stage (55 DAS). The entire dose of phosphorous@20 kg ha-1 as single super phosphate (SSP) and potassium @ $20 \mathrm{~kg} \mathrm{ha}^{-1}$ as muriate of potash (MOP) were applied as basal dose at the time of sowing.
Five plants were selected at random from net plot area and labeled with tags for recording growth attributes throughout the crop growing period. At harvesting, those 5 plants were sampled from the net plot of each plot to observe the yield attributes like number of panicles $\mathrm{m}^{-2}$, number of grains panicle $^{-1}$, number of filled grains panicle ${ }^{-1}$, length of the panicle and test weight. The grains and straw obtained from the net plot area including the sampled plants were thoroughly sun dried, weighed and expressed as $\mathrm{kg} \mathrm{ha}^{-1}$.

The data were statistically analyzed with standard method outlined for randomized block design factorial concept as described by Gomez and Gomez (1984) ${ }^{[4]}$. Statistically significance was tested by F-value at $0.05 \%$ level of probability and critical difference was worked out where ever the effect were significant.

\section{Results and Discussion \\ Yield}

The significantly higher grain and straw yields were produced by the application of $25 \%$ RDN through Vermicompost + $75 \% \operatorname{RDF}\left(\mathrm{T}_{2}\right)\left(2324 \mathrm{~kg} \mathrm{ha}^{-1}\right)$ compared to all other combinations of integrated nutrient management and control (100\% RDF) however, it was statistically at par with $50 \%$ RDN through Vermicompost + 50\% RDF $\left(\mathrm{T}_{5}\right)\left(2187 \mathrm{~kg} \mathrm{ha}^{-1}\right)$. The choice of varieties had no significant effect on grain and straw yields, both the varieties performed equally in response to different INM practices. Grain and straw yield were directly related with the growth and yield attributes. All the growth and yield attributes were higher with application of $25 \%$ RDN through Vermicompost $+75 \%$ RDF $\left(\mathrm{T}_{2}\right)$ and $50 \%$ RDN through Vermicompost $+50 \%$ RDF $\left(\mathrm{T}_{5}\right)$. The increased grain yield can be ascribed to the effect of adequate availability of NPK in soil solution by addition of vermicompost, might cause increase in root growth, thereby increasing uptake of nutrients. Higher grain and straw yield due to combined application of chemical fertilizers and organic manures might have attributed to sustained nutrient supply and also as a result of better utilization of applied nutrients through improved micro environmental conditions, especially the activities of soil microorganisms involved in nutrient transformation and fixation. These findings are in close agreement with those reported by Senapati et al. (2007) ${ }^{[6]}$, Basavaraju and Purushotha (2009) ${ }^{[1]}$, Chaudhari et al. (2011) ${ }^{[2]}$ in finger millet.

The harvest index remained non-significant with respect to varieties, integrated nutrient management practices as well as the interaction. The effect of integration of chemicals and organics on harvest index i.e., partitioning of photosynthates between vegetative and reproductive organs was nonsignificant indicating proportionate partitioning with increasing and decreasing supply of nitrogen and other nutrients.

Table 1: Grain yield, straw yield $\left(\mathrm{kg} \mathrm{ha}^{-1}\right)$ and harvest index (\%) of foxtail millet as influenced by varieties and integrated nutrient management.

\begin{tabular}{|c|c|c|c|}
\hline Treatments & Grain yield $\left(\mathbf{k g ~ h a}^{\mathbf{- 1}}\right)$ & Straw yield $\left(\mathbf{k g ~ h a}^{\mathbf{- 1}}\right)$ & Harvest index (\%) \\
\hline \multicolumn{3}{|c|}{ Varieties } & 34.23 \\
\hline $\mathrm{C}_{1}$ : SiA 3085 & 2048 & 3929 & 34.42 \\
\hline $\mathrm{C}_{2}$ : SiA 3156 & 2011 & 3820 & 0.55 \\
\hline $\mathrm{SEm} \pm$ & 43.4 & 46.5 & $\mathrm{NS}$ \\
\hline $\mathrm{CD}(\mathrm{P}=0.05)$ & $\mathrm{NS}$ & $\mathrm{NS}$ \\
\hline \multicolumn{2}{|c|}{ Integrated nutrient management } \\
\hline $\mathrm{T}_{1}$ Control(100\% RDF) & 1725 & 3353 & 33.97 \\
\hline $\mathrm{T}_{2}$ 25\% RDN Vermicompost + 75\% RDF & 2324 & 4353 & 34.35 \\
\hline $\mathrm{T}_{3}$ 25\% RDN FYM + 75\% RDF & 2087 & 3987 & 34.28 \\
\hline $\mathrm{T}_{4}$ 25\% RDN Sheep manure + 75\% RDF & 2058 & 3917 & \\
\hline
\end{tabular}




\begin{tabular}{|c|c|c|c|}
\hline $\mathrm{T}_{5} 50 \%$ RDN Vermicompost + 50\% RDF & 2187 & 4144 & 34.60 \\
\hline $\mathrm{T}_{6}$ 50\% RDN FYM + 50\% RDF & 1923 & 3720 & 34.08 \\
\hline $\mathrm{T}_{7} 50 \%$ RDN Sheep manure + 50\% RDF & 1903 & 3651 & 34.22 \\
\hline SEm \pm & 81.1 & 87.1 & NS \\
\hline CD $(\mathrm{P}=0.05)$ & 236.0 & 254.5 & 1.45 \\
\hline SEm \pm & Interaction & NS \\
\hline CD $(\mathrm{P}=0.05)$ & 114.7 & 123.1 & $\mathrm{NS}$ \\
\hline
\end{tabular}

\section{Economics}

Data pertaining to economics of foxtail millet showed that gross return, net return, B:C ratio were higher with variety SiA 3085 compared to $\mathrm{SiA} 3156$, however the differences were very less as both the varieties performed all most equally in response to integrated nutrient management practices.

Assessment of treatments in terms of economic traits revealed that the gross return, net returns and benefit cost $(\mathrm{B}: \mathrm{C})$ ratio differed due to different inorganic fertilizers and organic manures. Among the different treatments, 25\% RDN through Vermicompost $+75 \%$ RDF $\left(\mathrm{T}_{2}\right)$ recorded higher gross returns (37467 $\mathrm{Rs} \mathrm{ha}^{-1}$ ) than other combination of treatments. The next best treatment was 50\% RDN through Vermicompost + $50 \%$ RDF $\left(\mathrm{T}_{5}\right)$ having gross return of $35291 \mathrm{Rs} \mathrm{ha}^{-1}$. The higher gross return was mainly attributed to higher grain yield and straw yields. Net returns realized was more in $25 \%$ RDN through Vermicompost $+75 \% \mathrm{RDF}\left(\mathrm{T}_{2}\right)$. Higher net returns were obtained by the way of cutting down the expenditure on inorganic fertilizer, lesser cost of cultivation and also due to lower cost of organic manures viz., vermicompost compared to inorganic fertilizers. Similar findings also reported by Munirathnam et al. (2006) ${ }^{[5]}$ and Thimmaiah et al. (2016) ${ }^{[7]}$. Maximum benefit-cost ratio of 2.48 was recorded with $25 \%$ RDN through Vermicompost $+75 \% \operatorname{RDF}\left(\mathrm{T}_{2}\right)$.

Table 2: Economics of foxtail millet cultivation as influenced by varieties and integrated nutrient management.

\begin{tabular}{|c|c|c|c|c|}
\hline Treatments & Cost of cultivation (Rs. ha-1) & Gross returns (Rs. ha $\left.{ }^{-1}\right)$ & Net returns (Rs. ha $\left.{ }^{-1}\right)$ & B:C ratio \\
\hline \multicolumn{5}{|c|}{ Varieties } \\
\hline $\mathrm{C}_{1}: \mathrm{SiA} 3085$ & 14966 & 33080 & 17696 & 2.16 \\
\hline $\mathrm{C}_{2}: \mathrm{SiA} 3156$ & 14966 & 32459 & 17075 & 2.12 \\
\hline \multicolumn{5}{|c|}{ Integrated nutrient management } \\
\hline $\mathrm{T}_{1}$ Control(100\% RDF) & 13026 & 27879 & 14853 & 2.14 \\
\hline $\mathrm{T}_{2} 25 \%$ RDN Vermicompost $+75 \%$ RDF & 15122 & 37467 & 22345 & 2.48 \\
\hline $\mathrm{T}_{3} 25 \%$ RDN FYM + 75\% RDF & 14906 & 33732 & 18826 & 2.26 \\
\hline $\mathrm{T}_{4} 25 \%$ RDN Sheep manure $+75 \%$ RDF & 14551 & 33214 & 18663 & 2.28 \\
\hline $\mathrm{T}_{5} 50 \%$ RDN Vermicompost + 50\% RDF & 17218 & 35291 & 18073 & 2.05 \\
\hline $\mathrm{T}_{6} 50 \% \mathrm{RDN} F \mathrm{FM}+50 \% \mathrm{RDF}$ & 16786 & 31075 & 14288 & 1.85 \\
\hline $\mathrm{T}_{7} 50 \%$ RDN Sheep manure + 50\% RDF & 16075 & 30728 & 14653 & 1.91 \\
\hline
\end{tabular}

\section{Conclusion}

On the basis of experimental results, foxtail millet should be nourished with $25 \%$ RDN through Vermicompost $+75 \%$ RDF as this treatment reported higher grain and straw yield along with higher gross returns, net returns and B:C ratio. $50 \%$ RDN through Vermicompost $+50 \%$ RDF though found to be on par with $25 \%$ RDN through Vermicompost $+75 \%$ $\mathrm{RDF}$ in grain yiled, straw yield and net returns, but B:C ratio was low due to high cost of cultivation. If one can get the selfprepared manure in his backyard, the costs can be cut down to a largest extent and the foxtail millet could be nourished with $50 \%$ RDN through Vermicompost $+50 \%$ RDF. Any of the two varieties viz., SiA 3085 and SiA 3156 could be taken, as both the varieties performed equally with response to integrated nutrient management.

\section{References}

1. Basavaraju TB, Purushotham S. Integrated nutrient management in rainfed ragi (Eleusine coracana $\mathrm{L}$. Gartn.). Mysore Journal of Agricultural Sciences. 2009; 43(2):366-368.

2. Chaudhari PP, Patel DA, Virdia HM, Patel BM. Nutrient management in finger millet (Eleusine coracana L.) on hilly area of South Gujarat. Green farming. 2011; 2(6):658-660.

3. Choudhary R, Yadav LR, Parihar S. Studies on the interactive effect between vermicompost and fertility levels of pearl millet. Annals of Agri-bio Research. 2014; 3:430-433.
4. Gomez KA, Gomez AA. Statistical procedure for agriculture research. John Wiley and Sons Publishers, New York. 1984, 357-423.

5. Munirathnam P, Reddy A, Sambasiva, Sawadhkar SM. Evaluation of foxtail millet varieties under low fertility conditions. Agricultural Science Digest. 2006; 26(3):197199.

6. Senapati HK, Banddita J, Dash AK. Effect of vermicompost on ragi-tomato cropping systems. Environment and Ecology. 2007; 25(3):648-650.

7. Thimmaiah M, Dinesh KM, Nandish MS, Veeranna HK. Effect of integrated nutrient management on growth, yield and economics of rainfed finger millet (Eleusine coracana (L.) G.). Green Farming. 2016; 7(4):875-879.

8. Vanithasri J, Kanchana S, Hemalatha G, Vanniarajan C, Sahul HM. Role of millets and its importance in new mellinium. International Journal of Food Science and Technology. 2012; 2(1):35-47. 